\title{
Investigation of the Low Velocity Layer using Shallow Seismic Refraction Survey in Magadi Basin, Kenya
}

\author{
K’Orowe M. O ${ }^{1^{*}}$, Mulumbu B. E ${ }^{1^{*}}$, Githiri J. G. ${ }^{1}$ \\ ${ }^{I}$ (Department of Physics, Jomo Kenyatta University of Agriculture and Technology, Nairobi)
}

\begin{abstract}
Shallow seismic refraction survey of the low velocity layer $(L V L)$ is vital part of seismic data acquisition, processing and interpretation as it influences seismic reflection travel time. In the southern part of Kenya, a total of 90 forward and reverse-shooting shallow seismic refraction survey stations was carried out and analyzed with the aim of unraveling the geophysical characteristics of the weathered layer in "Block 14T", of Magadi Basin. Results from the generated Isopachs and Isovels show a dominant 2-weathered layer model in the area of study with a consolidated/bedrock zone observed from the velocity of the third layer. Velocity and thickness contour maps generated geostatistically show that both the velocity and thickness of LVL decreases towards the south with the least thickness observed in the south west and most thickness is observed in the East and around Lake Magadi. High velocities are observed in the northern part of the study region and low velocities are observed in the southern regions.
\end{abstract}

Keywords: Magadi Basin, seismic refraction, Intercept time, Isopach, Isovel

\section{Introduction}

On the onshore, there is a general surface whose seismic velocity is much lower than normal referred as the weathered layer or low velocity layer (LVL). This layer is usually some few metres thick, but may occasionally reach a thickness of several tens of metres depending on the geological nature of the subsurface. Often, the thickness of this layer is both laterally and vertically highly variable along a line leading to significant seismic time delays of magnitude dependent on the positions (elevations) of the shot and detector. These time delays, if not accounted for, degrade the reflection seismic section by improper alignment of traces. These near surface zone has various properties. Its top sediments are usually aerated, loose, unconsolidated with abnormally low velocities. It has variable thicknesses, densities and lithologies. It is characterized by low transmission of seismic waves and shots taken in this layer tend to be of low frequencies as the layer is capable of absorbing high frequency signals. Different studies have been done to understand characteristics of this weathered layer for example, Amonieah and Alaminiokuma, [1] geostatistically developed near surface structural model from a sample density of 36 Uphole/LVL survey points to determine the properties of the weathered layer in Niger Delta. The results served as baseline data for future 4D seismic data acquisition for accurate mapping of the deep underlying structures for oil and gas exploration in the North-Central part of the Niger Delta. Shallow seismic refraction data is also commonly used in oil and gas exploration to compute static correction for seismic reflection surveys. However, in order to obtain static correction the knowledge of the velocity and thickness of the weathered layers is significant. The static corrections obtained are used to adjust travel times for passage through the thick low-velocity "weathered zone" overlying solid rock. Lawton [2] observed that absolute values of the static corrections were less than $10 \mathrm{~ms}$, had greater effect on reflection travel times than does the surface topography and increased in response to the increasing thickness of glacial overburden in Southern Alberta, Calgary, (Lawton, 1989). Kolawole et al., [3] analyzed downhole refraction survey studies in Niger Delta Basin and showed lithological successions; velocities and depths of boundaries suggested an irregularity caused by faulting along the true base of weathering. Anomohanran, [4] observed weathered layer in Escravos averaged at depth of 3.68m and Saha et al., [5] observed significant variations in local as well as regional scale of velocitythickness maps in Assam Basin. In this study, use is made first breaks to determine the depth of the weathered zone and number of layers in weathered zone in Magadi basin (BLOCK 14T). Finally, using the thicknesses and velocities obtained, distribution of velocities and thickness is obtained by plotting the results using the surfer 10.0 software.

\subsection{Study Area and Geology of the study Area.}

Magadi basin is located in Kajiado County, approximately $100 \mathrm{~km}$ from Nairobi. The study area is bounded by latitudes $1^{0} 40^{\prime} \mathrm{S}$ and $2^{0} 10^{\prime} \mathrm{S}$ and Longitudes $36^{\circ} 00^{\prime} \mathrm{E}$ and $36^{\circ} 30^{\prime} \mathrm{E}$ as illustrated in figure 1 . It is in the Southern part of the Gregory Rift of continental type rift type. It extends from the Magadi to Natron, a quaternary basin in the south to Baringo and Suguta grabens in the north; a complex grabens bisecting the Kenya domal uplift. The lake Magadi is located in a broad flat depression with the lowest point in the Southern part of the Kenya Rift Valley. 


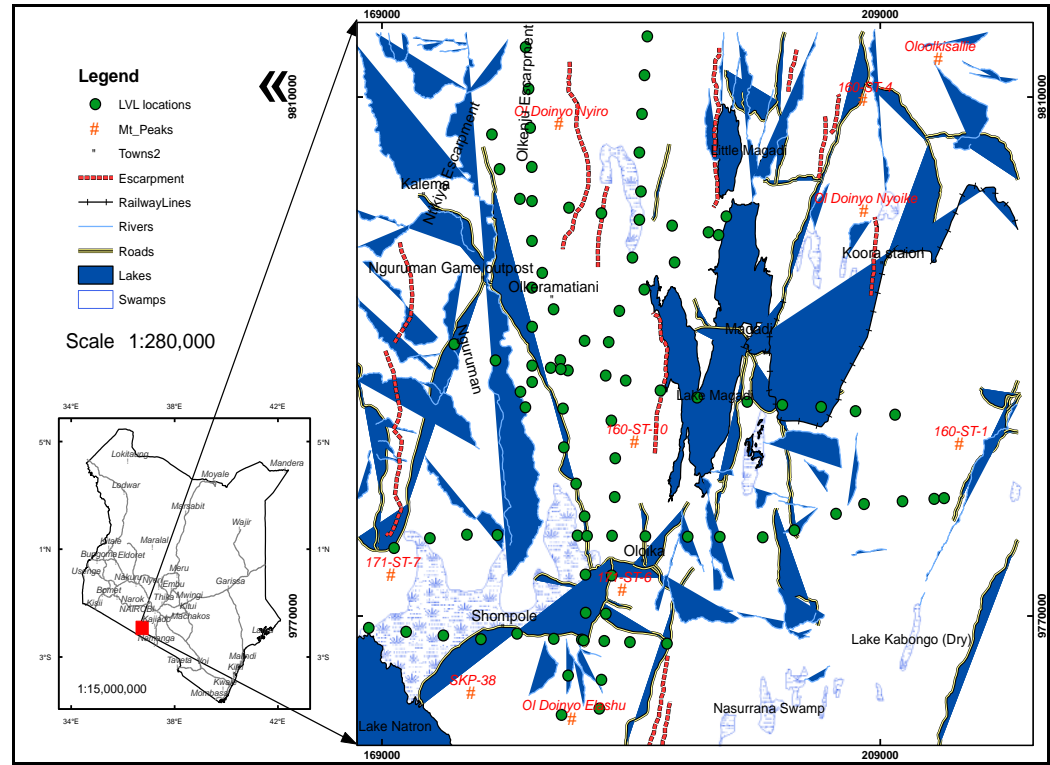

Figure 1: The study area of Magadi

\subsection{Geology of the Study Area}

The Magadi basin is classified into three formations [6,7] namely Precambrian metamorphic rocks, Plio-Pleistocene volcanics, the Holocene to recent lake and fluvial sediments. The basement rocks outcrop in the region west of the Nguruman escarpment. These rocks consist mainly of regular banded schists, gneisses and muscovite-rich quartzites. Baker, [7] found that the olivine basalt layers of the Kirikiti platform are interbedded with conglomerates; gravels and sands deposited between different eruption episodes. Three central volcanoes exist; olorgesailie, Oldoinyo Nyokie and Shompole as illustrated in Fig. 1. Olorgesailie is the highest. Its lava composition consists of olivine basalts, alkali trachyte and nephelinite. Further south, the Lenderut volcano dated 2.5 Ma has basalt and andesite lavas, while Shompole dated 2.0 Ma consists of carbonates and nephelinite rocks, [7]. The most extensive volcanic activity in the area occurred between 1.4 and $0.7 \mathrm{Ma}$, [8]. During this period the Magadi Trachyte series were formed and consisted of alkali lava sheets extending many kilometers that overlie most of the volcanics in the area. Magadi trachytes were followed by development of ash and lava vents and small obsidian lava volcano Oldoinyo Nyokie marking the end of volcanism in the southern Kenya Rift. Lacustrine and fluviatile sediments were last geological formations. Lake bed lay in the bottom of fault troughs and depressions mostly covered by alluvial silts, clays and boulder beds. These are exposed around Lake Magadi mainly in the Eastern trough of the lake. The fluviatile sediments are mainly located in the Ewaso Ngiro Basin. Other superficial deposits are the alluvium and soil filled Kordjya basin and Kora Basin, [6].

\subsection{Theory}

\section{Intercept Time Method}

From a typical seismic source, the direct ray travels along a straight line of distance $\mathrm{x}$ to the detector at velocity $\mathrm{V}_{0}$. The travel time of direct ray is given by;

$\mathrm{t}_{\text {direct }}=x / V_{0}$ .. 1

which defines a straight line slope passing through the origin of the time-distance graph, [9]. The inverse of the slope of the Time - Distance graph gives the velocity of the first layer. Subsequently, the inverse of the second layer and third layer are the velocities of the second and the third layer respectively. The thickness $Z_{0}$ and $Z_{1}$ is deduced from the point of intersection (inflexion point) of the two layers by using the equations 2 and 3 of time intercept method.

$Z_{0}=\frac{t_{0}}{2}\left(\frac{V_{1} V_{0}}{\sqrt{\left(V_{1}^{2}-V_{0}^{2}\right)}}\right)$ 


$$
Z_{1}=\frac{1}{2}\left[t_{1}-\frac{2 Z_{0} \sqrt{\left(V_{2}^{2}-V_{0}^{2}\right)}}{V_{2} V_{0}}\right] \frac{V_{2} V_{1}}{\sqrt{\left(V_{2}^{2}-V_{1}^{2}\right)}}
$$

Where: $t_{0}$ and $t_{1}$ are the intercept times on the Distance-Time graph. $V_{0}, V_{1}$ and $V_{2}$ are the velocity of the weathered zone, semi-weathered zone and the bedrock/consolidated zone respectively.

The total thickness of the weathering zone is given by equation 4 below:

$\mathrm{Z}_{\mathrm{W}}=\mathrm{Z}_{0}+\mathrm{Z}_{1}(\mathrm{~m})$ 4

\subsection{Field work and Data Acquisiton}

\section{Methodology}

The shallow refraction survey covered the whole area of Magadi basin with LVL stationed at an interval of approximately $3 \mathrm{~km}$ with a spread length of $108 \mathrm{~m}$ at each of the 90 stations (figure 1). The minimum offset was $20 \mathrm{~cm}$ at each station. A 24 channel receiver was used to record the seismic waves and a sledge hammer used as a source of seismic waves. A pre calibrated rope of $108 \mathrm{~m}$ was used as a guide to map geophone location at each station. DAQLink III received seismic waves and converted the analogue signals to a digital signal. Stack of 10-15 shots was made for forward and reverse to minimize background noise effects and to increase signal to noise ratio enabling first breaks to be seen clearly. Quality control was done during recording to eliminate noise and to ensure the signals recorded have less/free of noise. The sampling rate of $125 \mu \mathrm{s}$ with recording length of $500 \mathrm{~ms}$ was used

\subsection{Data Processing/ Analysis}

The acquired data was uploaded to the computer and imported into the Vista 2D/3D Software version 9.0 for processing. The imported data for each station comprising 10-15 shots was stacked into a single data of 24 traces. This was done for forward and reverse shots for each station followed by first break time picking. Data was recorded to Vscoope database and exported to SEG-Y file. SEG-Y files were transcribed to Vista for first break picking. The first break times picked were then loaded into spreadsheet where time distance graphs were plotted. Layers were picked, velocities and thicknesses determined calculated for each refraction station. The slope for each of the three layers were calculated using equation 1. A reciprocal of their slopes gave velocity of the weathered, semi weathered and the consolidated layers respectively. The depth to the refractor were also calculated from the point of intersection of the three slopes (point of inflexion) using the intercept time method. The intercept time is the interpolated intersecting point of the linear function to an offset equal to zero and is normally directly related to the depth of the refractor below the shotpoint, Knodel et al., [10]. The velocity in the (lower) refracting layer is derived from the reciprocal slope of the traveltime graph, Fig. 2

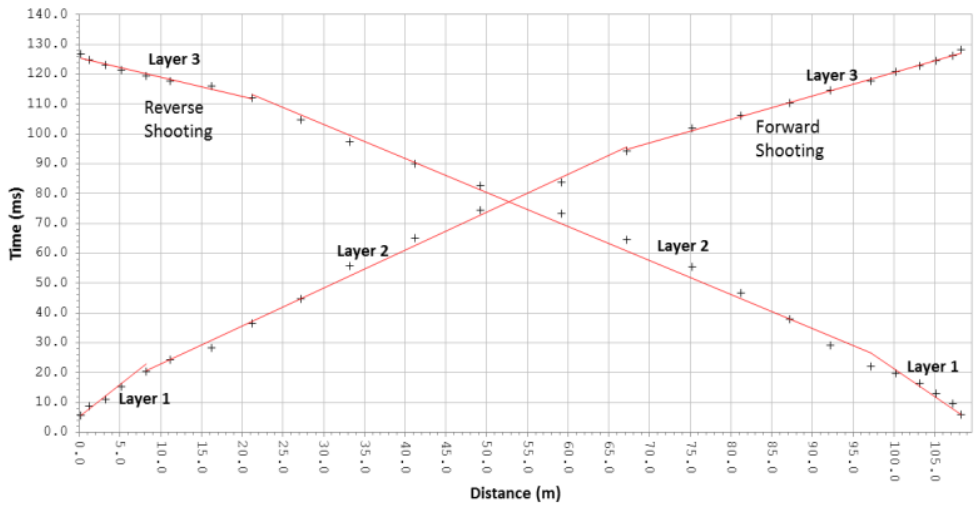

Figure 2 : LVL data for station 3953 showing time-graph plot for forward and reverse shooting.

By application of equation 1, the reciprocal of the slopes for each layer in figure 5 gives velocity of the first, the second and third layer of this station as $358.089 \mathrm{~m} / \mathrm{s}, 785.61 \mathrm{~m} / \mathrm{s}$ and $1265.34 \mathrm{~m} / \mathrm{s}$ respectively. Intercept time equations 2 and 3 were applied to calculate the thickness of the first layer and second layer whose depths are $2.1 \mathrm{~m}$ and $20.8 \mathrm{~m}$ respectively thereby giving a total depth $22.9 \mathrm{~m}$ to the bedrock for forward shooting. This process was repeated for reverse shooting and the velocities of $537.11 \mathrm{~m} / \mathrm{s}, 879.12 \mathrm{~m} / \mathrm{s}$ and $1552.31 \mathrm{~m} / \mathrm{s}$ obtained for first, second and third layer while thicknesses of $3.4 \mathrm{~m}$ and $29.7 \mathrm{~m}$ respectively. The total thickness was 33.1 $\mathrm{m}$ to the consolidated zone for reverse shooting. These are apparent velocities and depths for each of the layers. 
To determine true velocities and depths of layers, an average of the velocities and thicknesses for forward and reverse shooting was done to obtain the true velocities and depths of the each layer for this station, [10]. In this case, the average velocities for this station are $447.6 \mathrm{~m} / \mathrm{s}, 832.365 \mathrm{~m} / \mathrm{s}$ and $1408.83 \mathrm{~m} / \mathrm{s}$ for the first, second and third layers respectively; the average depths are $2.75 \mathrm{~m}$ and $25.25 \mathrm{~m}$ for the first and second layers respectively with cumulative average depth to the bedrock of $28 \mathrm{~m}$. This results were then summarized in table form as shown in the table 1.

\begin{tabular}{|c|c|c|c|c|c|c|c|c|c|c|c|}
\hline \multicolumn{6}{|c|}{ Interpretation Result for forward shooting } & \multicolumn{6}{|c|}{ Interpretation Result for reverse shooting } \\
\hline $\mathrm{V}_{0} \mathrm{~m} / \mathrm{s}$ & $\mathrm{V}_{1} \mathrm{~m} / \mathrm{s}$ & $\mathrm{V}_{2} \mathrm{~m} / \mathrm{s}$ & $\begin{array}{l}\text { DepthZ } \\
(\mathrm{m})\end{array}$ & $\begin{array}{l}\text { Depth } Z_{1} \\
\text { (m) }\end{array}$ & $\begin{array}{l}\text { Total Depth } \\
\left(\mathrm{Z}_{0}+\mathrm{Z}_{1}\right)(\mathrm{m})\end{array}$ & $\mathrm{V}_{0} \mathrm{~m} / \mathrm{s}$ & $\begin{array}{l}\mathrm{V}_{1} \\
\mathrm{~m} / \mathrm{s}\end{array}$ & $\begin{array}{l}\mathrm{V}_{2} \\
\mathrm{~m} / \mathrm{s}\end{array}$ & $\begin{array}{l}\text { Depth } Z_{0} \\
(\mathrm{~m})\end{array}$ & $\begin{array}{l}\text { Depth } Z_{1} \\
(\mathrm{~m})\end{array}$ & $\begin{array}{l}\text { Total Depth } \\
\left(\mathrm{Z}_{0}+\mathrm{Z}_{1}\right)(\mathrm{m})\end{array}$ \\
\hline 358 & 785.6 & 1265 & 2.1 & 20.8 & 22.9 & 422 & 879 & 1552 & 3.4 & 29.7 & 33.0 \\
\hline \multicolumn{12}{|c|}{ Final Interpretation Result (Average of the results) } \\
\hline \multicolumn{2}{|l|}{$\mathrm{V}_{0}(\mathrm{~m} / \mathrm{s})$} & \multicolumn{2}{|c|}{$\mathrm{V}_{1}(\mathrm{~m} / \mathrm{s})$} & \multicolumn{2}{|l|}{$\mathrm{V}_{2}(\mathrm{~m} / \mathrm{s})$} & \multicolumn{2}{|c|}{$\begin{array}{l}\text { Thickness }\left(\mathrm{Z}_{0}\right) \\
(\mathrm{m})\end{array}$} & \multicolumn{2}{|c|}{$\begin{array}{l}\text { Thickness } \quad\left(\mathrm{H}_{1}\right) \\
(\mathrm{m})\end{array}$} & \multicolumn{2}{|c|}{ Depth Z (m) } \\
\hline \multicolumn{2}{|l|}{447.1} & \multicolumn{2}{|l|}{832.4} & \multicolumn{2}{|l|}{1408.8} & \multicolumn{2}{|l|}{2.7} & \multicolumn{2}{|l|}{25.3} & \multicolumn{2}{|l|}{28.0} \\
\hline
\end{tabular}

\subsection{Weathered Layer/ first layer}

\section{Results and Discussion}

The average results obtained in table 3 for each station were used to plot contour maps in the survey area by geostatistical process of kriging. Isovels and isopachs were plotted on surfer 10.0 software. A distribution of seismic velocities and respective thicknesses for different layers across the study area was presented and discussed below
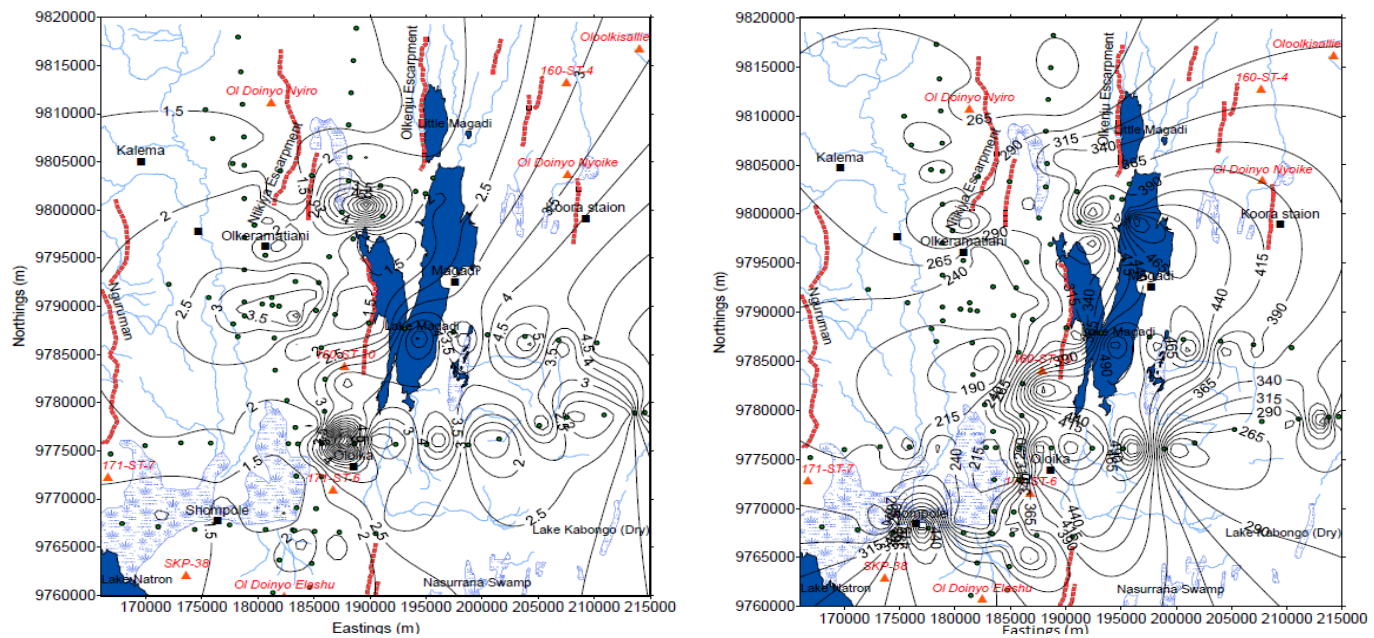

Figure 3. Isopach contour map of layer 1 in Magadi Area with contour interval $1 \mathrm{~m}$ (left) and Velocity Contour Map of layer 1 in Magadi basin with contour interval of $25 \mathrm{~m} / \mathrm{s}$, (right).

Low thicknesses less than $2.5 \mathrm{~m}$ are observed in the Western part of the Magadi basin, Fig. 3. The thicknesses of less than $1.5 \mathrm{~m}$ are observed in south western and north western region of study. This low thickness can be attributed to weathering and erosion of the top surface as the layer lies towards the Nguruman escarpment. The regions close to Nguruman escarpment is slightly steeper and experiences more erosion which could result to a thin first layer. In the southwestern side of study area; the regions encompassing Shompole and areas towards Lake Natron and swampy regions of Mbakasi, the thickness of the first layer is thin with less than $1.5 \mathrm{~m}$. This could be due to erosion of sediments towards the Lake Natron resulting in very low thickness. Majority of western side of the study area have thickness of less than $2.5 \mathrm{~m}$ with patches close to Olkiramatian varying between $2.5 \mathrm{~m}-3.5 \mathrm{~m}$. The eastern side has thickness varying from $2.5-12 \mathrm{~m}$. It is the region with the much thickness in the first layer. This can be attributed to deposition of volcanic sediments mainly the trachytes, clays and cherts. It may also be due to deposited volcanic sediments and erosion from neighbouring volcanic features like Ol Doinyo Nyokie. This areas covers Lake Magadi and the eastern region of study area.

It is observed that the weathering velocity decreases generally towards the western side and increases towards the eastern side (Fig. 4). It then decreases towards Ol Doinyo Nyokie region. The low velocities in the first layer varies from 140- 290m/s and are mainly observed in the western and south eastern are of Magadi basin. This velocity are very low normally encountered in weathering zone. Higher velocities are observed at the center of the study area, the NW towards the southern area of study. In general, the velocity in the first layer increases towards the eastern side and decreases towards the western side of the study area. 


\subsection{Semi-Weathered Zone/Second Layer}

The semi-weathered zone has great depths towards the eastern part of the study area and within Lake Magadi (Fig. 5). Low thicknesses are observed in the SW part of the study area and East of shompole as well as in the swampy regions. The depths in this area vary from $12-14 \mathrm{~m}$. The thickness increases towards Nguruman escarpment and further towards the East. It is observed that as thickness decreases towards the south, so does the velocity (Fig. 6). Average thickness vary from 16-32m and are seen clearly in the western part of Magadi basin. Large depths greater than $32 \mathrm{~m}$ are observed in the eastern area of study. The velocity in the semi-weathered zone decreases southwards and westwards of the study area (Fig. 6). However, as the depth and elevation increase towards the east and North, so does the velocity of the semi weathered zone. Much of the region in the south still lies in the low velocity zone as evidenced by the low seismic velocity distribution of less than $1500 \mathrm{~m} / \mathrm{s}$ except the northern region. This high seismic velocities in the northern region could be due to bedrock of the volcanic rocks being exposed partly by hill wash and wind erosion of the neighbouring volcanic features like the Ol Doinyo Nyokie and Olorgesailie mountains, (Fig. 6). The large depths in Magadi area are composed of trona, clay, silts, mud and cherts forming the major part of semi-consolidated zone. Further, the outflowing of volcanic rock from the surrounding hot spring could aid in transportation of this sediments resulting in increased size of the LVZ.

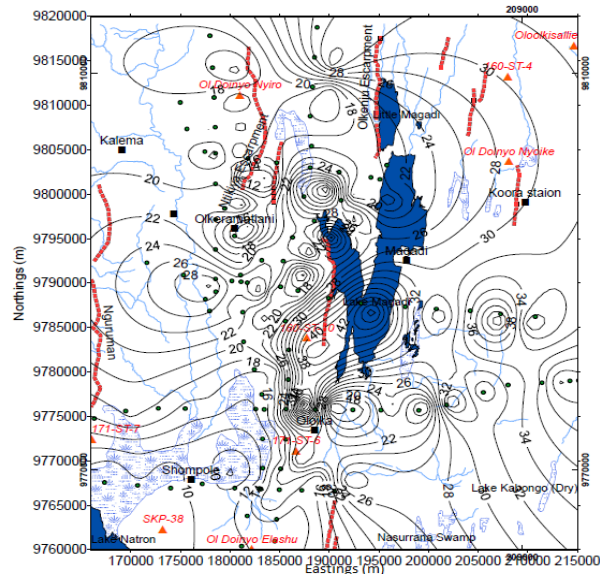

(a)

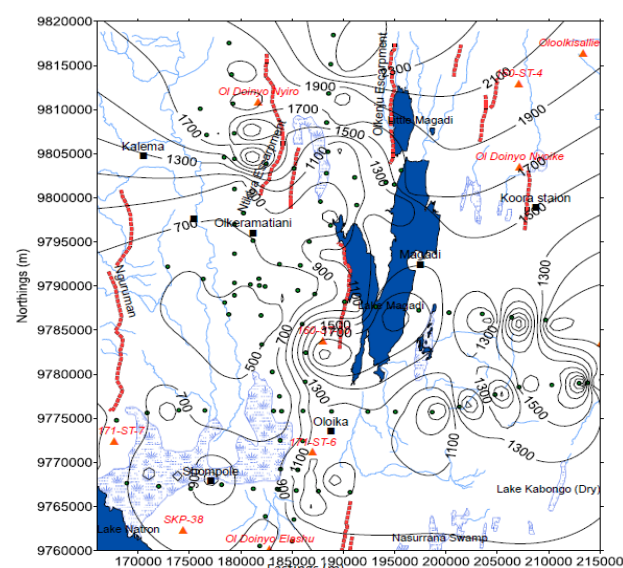

(b)

Figure 4: Isopach contour map of the second layer. Triangles shows LVL refraction points. Velocity contour map of the semi weathered zone

\subsection{Consolidated Zone/ The third Layer.}

The region exhibits high seismic velocity distribution in the northern part of study area, Fig. 7. There is sharp velocity variation in local scale of $3600 \mathrm{~m} / \mathrm{s}$ to $600 \mathrm{~m} / \mathrm{s}$ in some parts. This could be regions of nonhomogenous layers. Uniform velocity distribution traverses the central part of the study area passing through Lake Magadi towards the south as one approaches the swampy regions. Low velocity distribution is exhibited in the south western and south eastern parts of the study area. Velocities in this region vary from $600 \mathrm{~m} / \mathrm{s}$ to $1800 \mathrm{~m} / \mathrm{s}$ with some local region regions having velocities of $2500 \mathrm{~m} / \mathrm{s}$. The high velocities are observed in the northern parts with velocities of up to $3600 \mathrm{~m} / \mathrm{s}$

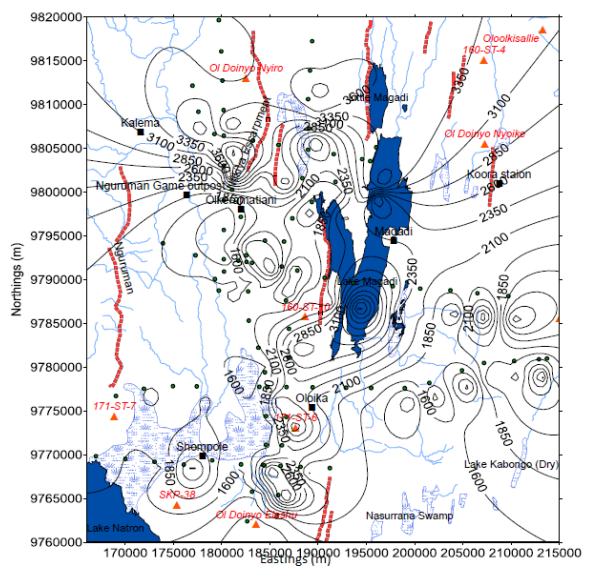

Figure 5: Velocity contour of the consolidated zone 


\section{Conclusions}

Magadi basin lies in the western rift valley. Normal faulting in the weathering layer is a normal occurrence. This is followed by hill wash and normal erosion on the surface which has allowed for more deposition of sediments in the Lake Magadi and the surrounding regions thereby significantly increasing the thickness of the weathered zone in this region. A three layer model of the low velocity zone is obtained; the weathered zone, the semi-weathered zone and the consolidated/ bedrock zone. The average thickness of the weathered layer to the top of the sub-weathered zone is $2.6 \mathrm{~m}$ with an average velocity of $310 \mathrm{~m} / \mathrm{s}$. The weathering thickness ranges from $0.5 \mathrm{~m}$ in the swampy areas of the southern parts and increases to $4.5 \mathrm{~m}$ in the Eastern parts with maximum thickness observed in Lake Magadi. The calculated velocity ranges from $145.1 \mathrm{~m} / \mathrm{s}$ in the south to $648.7 \mathrm{~m} / \mathrm{s}$ in the northern region in the first layer. The low weathering thicknesses and velocities observed in Shompole and swampy areas of the south through the south-west indicates the presence of loose unconsolidated and aerated soil materials mainly clay which may lead to high absorption of seismic energy. The sub-weathered zone has velocities ranging from $380.3 \mathrm{~m} / \mathrm{s}$ to $2802.3 \mathrm{~m} / \mathrm{s}$ with an average of $1085.5 \mathrm{~m} / \mathrm{s}$. The depths range from $7.4 \mathrm{~m}$ to $52.0 \mathrm{~m}$ with an average of $22.9 \mathrm{~m}$. The bedrock or the consolidated zone has a velocities ranging from $671.8 \mathrm{~m} / \mathrm{s}$ to $4844.4 \mathrm{~m} / \mathrm{s}$ with an average of $2208.1 \mathrm{~m} / \mathrm{s}$. The average depth from the weathered zone to the bedrock is $25.5 \mathrm{~m}$. Finally, it is observed that as the elevation decreases southwards and towards the east, so does the velocity and thickness of the weathered zone. The study suggests uphole survey to be carried in the area to fill up refraction survey that was carried out. Core samples can be obtained from uphole survey for further analysis to get the lithological characteristics of the low velocity layer in Magadi Basin. More meaningful seismic reflection work in the study area is required for substantial static corrections, owing to the high variability of weathered layer. The determined depths and velocities of the LVL in this region is significant information that could aid in determining static correction lead to better identification of structural and lithological features for hydrocarbon identification.

\section{Acknowledgements}

Many special thanks to the staff of Physics department of Jomo Kenyatta University of Agriculture and Technology (JKUAT) for their guidance through the duration of this project. My sincere thanks to National Oil Corporation of Kenya, NOCK, and Japan's JOGMEC for allowing me access the shallow refraction seismic data for this project and Polaris Seismic International Ltd for teaching me and allowing me use their software for data processing and interpretation.

\section{References}

[1] Amonieah J. and Alaminokuma G.I., (2012). Near-surface structural model for enhanced seismic data acquisition and processing in North-Central Niger Delta. American Journal of Scientific and Industrial Research, 3 (5): 252-262.

[2] Lawton C. D., (1989). Computation of refraction static using first-break travel time differences. Geophysics, 54 (10): $1289-1296$

[3] Kolawole F., Okror C. and Olaleye O.P., (2012). Downhloe Refraction Survey in Niger Delta Basin: A 3- layer Model. APRN Journal of Earth Sciences. 1 (2): 67-79.

[4] Anomohanran O., (2014). Downhole seismic refraction survey of weathered layer characterization in Escravos, Nigeria. American Journal of Applied Sciences, 11 (3): 371-380.

[5] S. Saha, A. Mandal, B. Borah and M. Gupta, "Characteristics of Low Velocity Layer in Upper Assam Basin near Naga Thrust: A brief Study", 9th Biennial International Conference and Exposition on Petroleum Geophysics, Hyderabad, 2012, pp. $249-253$.

[6] Baker B., (1958). Geology of the Magadi area. Report geological survey of Kenya 42. The government Printer, Nairobi.

[7] Baker B., (1963). Geology of the area of the South Magadi. Report Geological survey of Kenya 61. The government Printer, Nairobi.

[8] Crossley R., (1979). Structure and Volcanism in the Southern Kenya Rift. In Geodynamic evolution of the Afro-Arabian Rift system. Academic, 89-98.

[9] Keary P., Brooks M. and Hill I., (2005). An introduction to Geophysical Exploration. Blackwell Scientific Publications.

[10] K. Knödel, G. Lange and H.N. Voigt, Environmental Geology: Handbook of Field Methods and Case Studies, Springer. Verlag: Berlin Heidelberg, 2007. 